
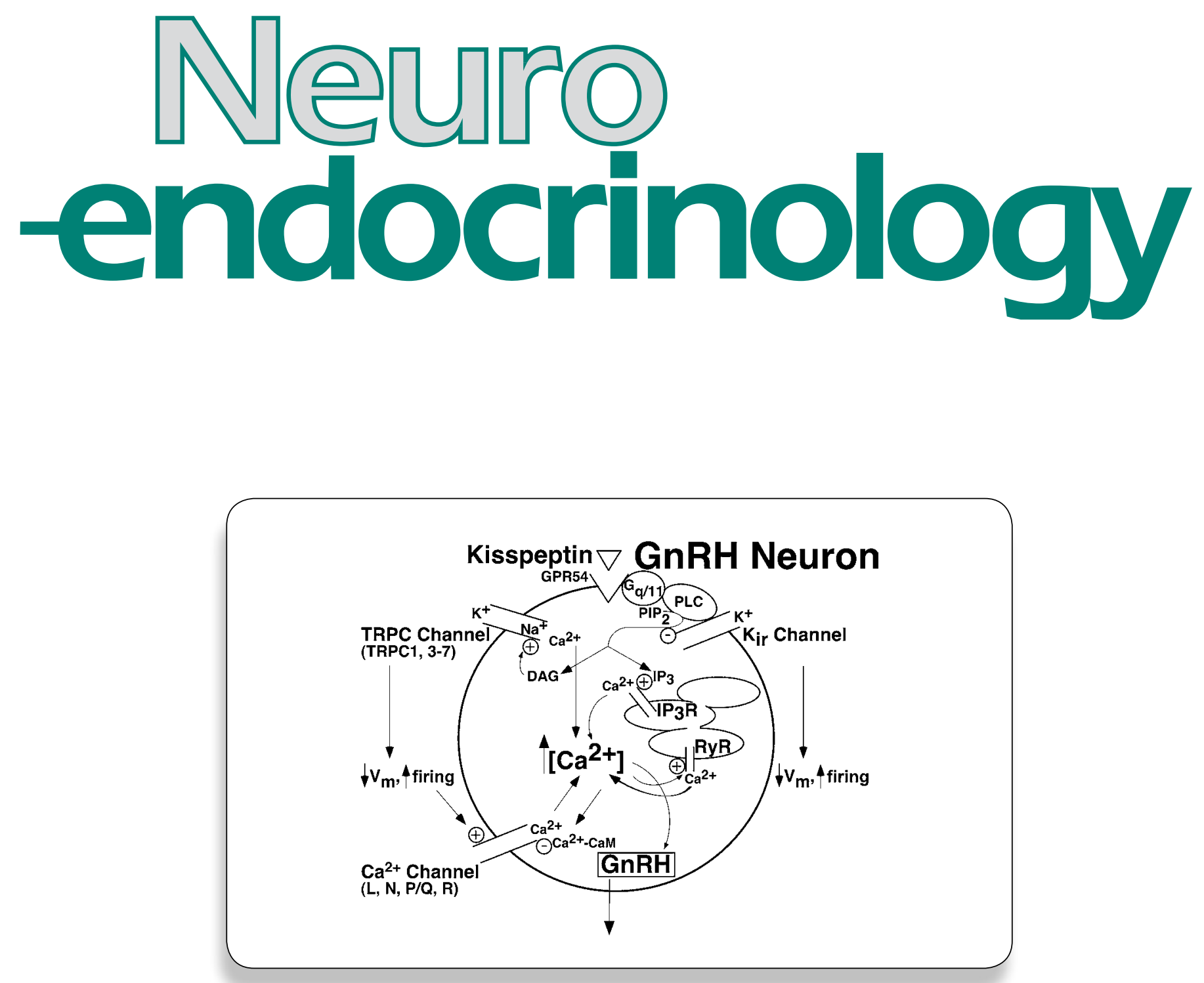

Medical and Scientific Publishers Basel · Freiburg · Paris .

London - New York ·

New Delhi · Bangkok · Beijing ·

Tokyo · Kuala Lumpur ·

Singapore · Sydney 


\section{Towards a holistic way of understanding and treating asthma and allergy}

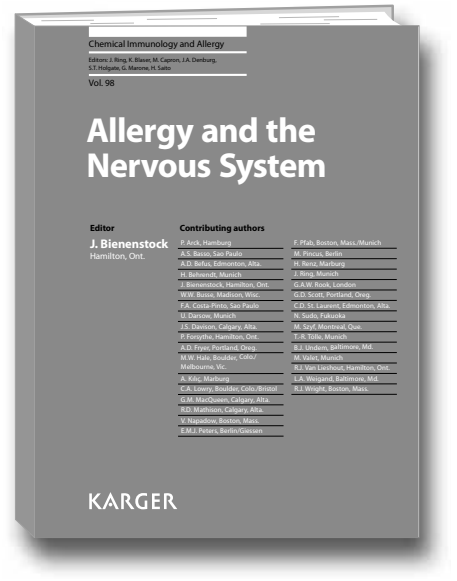

In recent decades, it has become increasingly clear that the immune and nervous systems communicate with each other in a bidirectional way. The role of chronic stress in allergic disease and inflammation has been confirmed and raises the important question of how psychosocial factors influence the outcome of allergic conditions.

This book explains the roles of the autonomic, peripheral and central nervous systems in allergy and asthma. With contributions from leading authorities - both clinicians and basic researchers - it covers a wide range of topics from psychology over epigenetics to brain imaging. The 15 invited reviews discuss topics such as the role of stress in allergy and asthma, the concept of programming in utero and in childhood and adulthood, the significance of neurotrophins, and the involvement of the nervous system in the lung in asthma and lung inflammation. The interactions between mast cells and the nervous system are examined as well as the role of the gut microbiome in regulating the hypothalamic-pituitary-adrenal axis and the stress response. Further chapters are devoted to neural and behavioral changes associated with food allergy, the role of the neuroendocrine system in the skin, and the way in which itch is processed by the brain.

Unique in its field, this valuable volume is recommended reading not only for allergologists, psychologists specializing in allergy and somatic manifestations, respirologists and asthma researchers, but for anyone interested in psychoneuroimmunology.

\section{Allergy and the Nervous System}

\author{
Editor \\ John Bienenstock
}

\section{Contents}

\section{Preface: Bienenstock, J.}

Relations between Asthma and Psychological Distress: An Old Idea Revisited: Van Lieshout, R.J.; MacQueen, G.M.

The Brain and Asthma: What Are the Linkages?: Busse, W.W.

Stress-Related Programming of Autonomic Imbalance: Role in Allergy and Asthma: Wright, R.J.

Role of Parasympathetic Nerves and Muscarinic Receptors in Allergy and Asthma: Scott, G.D.; Fryer, A.D.

Developmental Programming of Allergic Diseases: Pincus, $\boldsymbol{M}$.; $\boldsymbol{A r c k}, \boldsymbol{P}$.

Mind-Body Interrelationship in DNA Methylation: Szyf, $\boldsymbol{M}$.

Neurotrophins in Chronic Allergic Airway Inflammation and Remodeling: $\boldsymbol{R e n z}, \boldsymbol{H}_{\text {,; }}$ Kılıç, $A$.

Pathways Underlying Afferent Signaling of Bronchopulmonary Immune Activation to the Central Nervous System: Hale, M.W.; Rook, G.A.W.; Lowry, C.A.
Allergen-Induced Neuromodulation in the Respiratory Tract: Weigand, L.A.; Undem, B.J.

Role of Microbiome in Regulating the HPA Axis and Its Relevance to Allergy: Sudo, $\boldsymbol{N}$.

Autonomic Regulation of Anti-Inflammatory Activities from Salivary Glands: Mathison, R.D.; Davison, J.S.; St. Laurent, C.D.; Befus, A.D.

The Mast Cell-Nerve Functional Unit: A Key Component of Physiologic and Pathophysiologic Responses: Forsythe, P.; Bienenstock, J.

Neural and Behavioral Correlates of Food Allergy: Costa-Pinto, F.A.; Basso, A.S.

The Neuroendocrine-Immune Connection Regulates Chronic Inflammatory Disease in Allergy: Peters, E.M.J.

Itch and the Brain: Pfab, F.; Valet, $\boldsymbol{M}_{\text {.; }}$ Napadow, V.; Tölle, T.-R.; Behrendt, H.; Ring, J.; Darsow, $U$.

Author Index

Subject Index
Chemical Immunology and Allergy, Vol. 98 Series Editors: Ring, J. (Munich); Blaser, K. (Davos); Capron, M. (Lille); Denburg, J.A. (Hamilton); Holgate, S.T. (Southampton); Marone, G. (Naples); Saito, H. (Tokyo) ISSN 1660-2242 / e-ISSN 1662-2898

\section{Allergy and the Nervous System}

Editor: Bienenstock, J. (Hamilton, Ont.)

XII + 272 p., 51 fig., 4 tab., hard cover, 2012

CHF 196.- / EUR 163.- / USD 231.00

Prices subject to change

EUR price for Germany, USD price for USA only

ISBN 978-3-318-9984-9

e-ISBN 978-3-318-9985-6 www.karger.com/chial

\section{KARGER}

\section{Please send: \\ copy/ies}

Postage and handling free with prepayment

E

Please charge to my credit card

- $\square$ American Express $\square$ Diners

ᄂ $\square$ MasterCard $\square$ Visa

- Card No.

๑

Exp. date

CVV/CVC

( 3 digits in the signature field on the back of Visa and MasterCard)

$\square$ Check enclosed $\quad \square$ Please bill me

Orders may be placed with any bookshop, subscription agency, directly with the publisher or through a Karger distributor.

\section{Fax: +41 613061234}

S. Karger AG, P.O. Box, CH-4009 Basel (Switzerland) E-Mail orders@karger.ch, www.karger.com

Name/Address: 
Official Journal of

\begin{tabular}{ll}
\hline & $\begin{array}{l}\text { International } \\
\text { Neuroendocrine } \\
\text { Federation (INF) }\end{array}$ \\
\hline ENETS & $\begin{array}{l}\text { European } \\
\text { Eeuroendocrine } \\
\text { Association (ENEA) }\end{array}$ \\
\hline \multirow{2}{*}{$\begin{array}{l}\text { Eeuroendocrine } \\
\text { Tumor Society (ENETS) }\end{array}$} \\
\hline
\end{tabular}

\section{Editor-in-Chief}

R.P. Millar, Edinburgh

\section{Editorial Manager}

A. Ross, Edinburgh

\section{Editors}

I.J. Clarke, Clayton, Vic.

C. Coen, London

M.A. Cowley, Clayton, Vic.

W.W. de Herder, Rotterdam

A. Enjalbert, Marseille

A.B. Grossman, Headington

D. Jezová, Bratislava

A.S. Kauffman, La Jolla, Calif.

M.J. Kelly, Portland, Oreg.

P.A. Kelly, Paris

S.R. Ojeda, Beaverton, Oreg. (Reviews)

G. Rindi, Rome

M. Tena-Sempere, Cordoba

B. Wiedenmann, Berlin

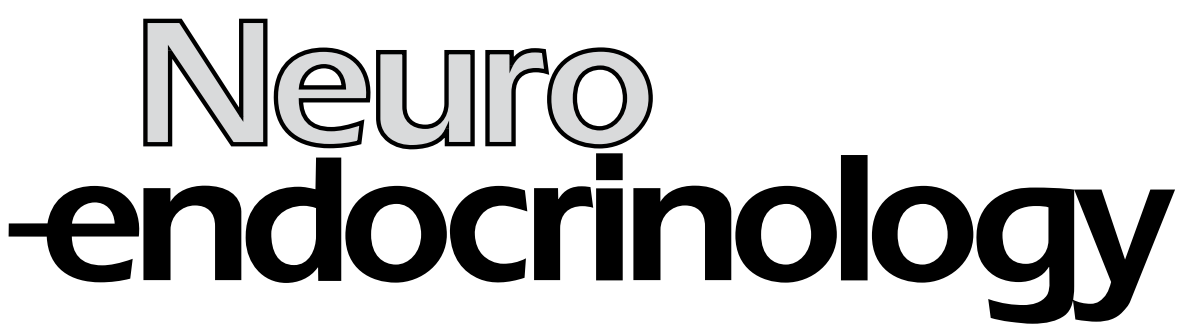

International Journal for Basic and Clinical Studies on Neuroendocrine Relationships

Founded 1965 by E. Bajusz

Continued by K.M. Knigge (1973-1978), W.F. Ganong (1979-1984),

S.M. McCann (1985-1993), C. Kordon (1994-2005)

\section{Editorial Board}

D.H. Abbott, Madison, Wisc.

H. Ahlman, Gothenburg

E. Arzt, Buenos Aires

A.V. Babwah, London, Ont.

T. Bartness, Atlanta, Ga.

C.L. Bethea, Beaverton, Oreg.

D.W. Brann, Augusta, Ga.

B. Canny, Monash, Vic.

M. Caplin, London

K. Catt, Bethesda, Md.

A. Chodobski, Providence, R.I.

W. de Herder, Rotterdam

S.L. Dickson, Gothenburg

J. Drouin, Montreal, Que.

P.J. Enriori, Monash, Vic.

W. Farrell, Keele

M. Freeman, Tallahasse, Fla.

A.C. Gore, Austin, Tex.

K. Grove, Beaverton, Oreg.

T. Harmar, Edinburgh

A. Herbison, Dunedin

J. Herman, Cincinnati, Ohio

J.J. Hirst, Callaghan, N.S.W.

T. Hökfelt, Stockholm

U. Kaiser, Boston, Mass.

K. Kim, Seoul

J.Z. Kiss, Geneva

A.C. Latronico, São Paulo

G. Leng, Edinburgh

J. Levine, Evanston, Ill.

C. Libertun, Buenos Aires

C. Llorens-Cortes, Paris

A. Lomniczi, Beaverton, Oreg.
A. Loudon, Manchester

Z.-L. Lu, Edinburgh

G. Martinez de la Escalera, Querétaro

R. Melcangi, Milano

I. Modlin, New Haven, Conn.

Z. Naor, Tel Aviv

M. Palkovits, Budapest

I. Parhar, Kuala Lumpur

D.W. Pfaff, New York, N.Y.

T.M. Plant, Pittsburgh, Pa.

J. Reul, Bristol

R. Reynolds, Edinburgh

E. Rissman, Charlottesville, Va.

J.L. Roberts, San Antonio, Tex.

I. Robinson, London

P. Ruszniewski, Clichy

W. Schlegel, Geneva

D. Skinner, Laramie, Wyo.

M. Sleeman, Clayton, Vic.

J. Smith, Perth, W.A.

E. Spinedi, La Plata

R. Steiner, Seattle, Wash.

E. Terasawa, Madison, Wisc.

A. Tilbrook, Roseworthy, S.A.

E. Wagner, Pomona, Calif.

B. Walker, Edinburgh

H. Watanobe, Chiba

M. Watt, Clayton, Vic.

M. Wierman, Denver, Colo.

J. Wingfield, Seattle, Wash.

S. Wray, Bethesda, Md.
Printed in Switzerland on acid-free and non-aging paper (ISO 9706) by Reinhardt Druck, Basel
Appears 6-weekly: 2 volumes per year (8 issues) 


\section{Neura \\ endocrinology}

The Editorial Board of Neuroendocrinology welcomes articles for review that report new observations on interactions between the brain and the endocrine system. Papers that are published deal with both basic and clinical subjects. Editorials, summaries of meetings, and reviews of timely topics in basic and clinical neuroendocrinology are also published, but these items are accepted only at the invitation of the Editor-in-Chief.

\section{Submission}

Manuscripts written in English should be submitted using the online submission website at:

www.karger.com/nen

or as e-mail attachment (the preferred word-processing package is MS-Word) to the Editorial Office:

editor@nen-edinburgh.org

Editorial Office 'Neuroendocrinology'

Prof. Dr. Robert Millar

South Lodge

295 Gilmerton Road

Edinburgh EH16 5UL (UK)

Tel. +441312080769

Editorial Manage

Dr. Allison Ros

editor@nen-edinburgh.org

Manuscripts should contain unpublished results of research work, and should be as concise as possible. The following presentation is recommended: Abstract, Introductory statement on the purpose of the studies, Materials and methods, Results, on the purpose of the studies, Materials and methods, Results,
Discussion, and References. Current abbreviations should be used throughout the text and tables (for pituitary hormones: ACTH, Th-END, FSH, GH, LH, TSH; for neuropeptides: CRH, not CRF; GAL; GHRH, not GRF; GnRH, not LHRH; NPY; NT; SRIH, not SRIF; VIP. .), and a definition should be provided the first time each abbreviation appears. Please limit abbreviations to those in common use, and avoid other ab breviations and acronyms. Manuscripts should contain novel, original data. As a rule, the Editorial office commits itself to achieve initial review of manuscripts within less than 60 days; average interval between submission and publication is 7-9 months. Authors of articles reporting mostly confirmatory, fragmentary or preliminary findings may be notified within 2 weeks that their manuscript will not be submitted to formal review. Such a proposal will be made by the associate Editors assisted by one member of the Editorial Board. This procedure is intended to provide rapid feedback to authors of manuscripts which have a poor chance of being accepted. Authors have the opportunity to appeal against the decision. Contributors should know that one of the criteria considered in reviewing manuscripts is the humane and proper treatment of animals. The editors realize that the use of anesthetics, analgesics, and tranquilizers would defeat the purpose of some experiments. However, the use of painful or otherwise noxious stimuli must be carefully and thoroughly justified in the paper. Papers that do not meet these criteria will not be accepted for publication.

\section{Conditions}

All manuscripts are subject to editorial review. Manuscripts are received with the explicit understanding that they are not under simultaneous consideration by any other publication. Submission of an article for publication implies the transfer of the copyright from the author to the publisher upon acceptance. Accepted papers become the permanent property of 'Neuroendocrinology' and may not be reproduced by any means, in whole or in part, without the written consent of the publisher. It is the author's responsibility to obtain permission to reproduce illustrations, tables, etc. from other publications.

\section{Arrangement}

Title page: The first page of each paper should carry the title, the authors full first and last names, and the name of the institute or department where the authors conducted their research work. In addition, the following should be put on the title page: 1. A short title for use as a running head. 2. A list of 3-9 key words that reflect the content of the paper. 3 . The name and complete mailing address as well as phone and fax numbers and e-mail address of the individual to whom correspondence, proofs, and requests for reprints should be addressed.

Abstract: Each paper must have a short abstract describing procedures, observations and conclusions, which will appear at the beginning of the article. Abstracts should not exceed 250 words.

Footnotes: Avoid footnotes if at all possible. When essential, they should be numbered consecutively and typed at the foot of the appropriate page.

Acknowledgments: Including, where relevant, credit to the sources of grant support.

Tables and illustrations: Tables (numbered in arabic numerals) should be prepared on separate sheets, and each should have a suitable heading. Illustrations should be numbered in Arabic numerals and legends for the figures should be submitted on a separate page. For the reproduction of illustrations, only good drawings and original photographs can be accepted; negatives or photocopies cannot be used. Due to technical reasons, figures with a screen background should not be submitted. When possible, group several illustrations on one block for reproduction (max. size $180 \times 223 \mathrm{~mm}$ ) or provide crop marks. Electronically submitted b/w half-tone and color illustrations must have a final resolution of $300 \mathrm{dpi}$ after scaling, line drawings one of 800-1200 dpi.

References: In the text identify references by Arabic numerals [in square brackets]. Material submitted for publication but not yet accepted should be noted as 'unpublished data' and not be included in the reference list. The list of referenc es should include only those publications which are cited in the text. Do not alphabetize; number references in the order in which they are first mentioned in the text. The surnames of all the authors followed by initials should be given. There should be no punctuation other than a comma to separate the authors. Preferably, please cite all authors. Abbreviate journa names according to the Index Medicus system. Also see International Committee of Medical Journal Editors: Uniform requirements for manuscripts submitted to biomedical journals (www.icmje.org)

Examples:

(a) Papers published in periodicals: Sun J, Koto H, Chung KF: Interaction of ozone and allergen challenges on bronchial responsiveness and inflammation in sensitised guinea pigs. Int Arch Allergy Immunol 1997;112:191-195.

(b) Papers published only with DOI numbers:

Theoharides TC, Boucher W, Spear K: Serum interleukin-6 reflects disease severity and osteoporosis in mastocytosis patients. Int Arch Allergy Immunol DOI: 10.1159/000063858. (c) Monographs: Matthews DE, Farewell VT: Using and Understanding Medical Statistics, ed 3, revised. Basel, Karger, 1996.

(d) Edited books: Parren PWHI, Burton DR: Antibodies against HIV-1 from phage display libraries: Mapping of an mmune response and progress towards antiviral immunotherapy; in Capra JD (ed): Antibody Engineering. Chem Immunol. Basel, Karger, 1997, vol 65, pp 18-56.

Papers that have been submitted to a journal but are not yet accepted should not be listed in the bibliography, but the dat in them can be referred to in the text as unpublished observations. If details of methods are only available in papers that are 'in press', copies of the papers should be included with the manuscript submitted to 'Neuroendocrinology', so that the editorial referees can have adequate information to judge the manuscript.

Reference Management Software: Use of EndNote is recommended for easy management and formatting of citations and reference lists.
Digital Object Identifier (DOI)

S. Karger Publishers supports DOIs as unique identifiers for articles. A DOI number will be printed on the title page of each article. DOIs can be useful in the future for identifying and citing articles published online without volume or issue information. More information can be found at www.doi.org.

\section{Author's Choice ${ }^{\mathrm{TM}}$}

Karger's Author's Choice ${ }^{\mathrm{TM}}$ service broadens the reach of your article and gives all users worldwide free and full access fo reading, downloading and printing at www.karger.com. The option is available for a one-time fee of CHF 3000.-, which is a permissible cost in grant allocation. More information can be found at www.karger.com/authors_choice.

\section{NIH-Funded Research}

The U.S. National Institutes of Health (NIH) mandates under the NIH Public Access Policy that final, peer-reviewed manuscripts appear in its digital database within 12 months of the official publication date. As a service to authors, Karger submits the final version of your article on your behalf to PubMed Central. For those selecting our premium Author's Choice ${ }^{\mathrm{TM}}$ service, we will send your article immediately upon publish ing, accelerating the accessibility of your work without the usual embargo. More details on NIH's Public Access Policy is available at http://publicaccess.nih.gov/policy.htm

\section{Self-Archiving}

Karger permits authors to archive their pre-prints (i.e. prerefereeing) or post-prints (i.e. final draft post-refereeing) on their personal or institution's servers, provided the following conditions are met: Articles may not be used for commercial purposes, must be linked to the publisher's version, and must acknowledge the publisher's copyright. Authors selecting Karger's Author's Choice ${ }^{\mathrm{TM}}$ feature, however, are also permitted to archive the final, published version of their article, which includes copyediting and design improvements as well as citation links.

Proofs

Unless indicated otherwise, a PDF for correction is sent to the corresponding author and should be returned with the least possible delay. Alterations other than the correction of printer's errors are charged to the author.

\section{E-pub First}

All articles are published electronically ahead of print with a DOI number and are supplemented later with the definite reference of the printed version. The articles become available immediately after the authors" approval to publication, with the added advantage of being citable much earlier than in print. Authors can influence the time of appearance by promptly returning the proofs.

Reprints

Order forms and a price list are sent with the PDF. Order submitted after the issue is printed are subject to considerably higher prices.

\section{Supplementary Materia}

Supplementary material is restricted to additional data that are not necessary for the scientific integrity and conclusion of the paper. Please note that all supplementary files will undergo editorial review and should be submitted together with the original manuscript. The Editors reserve the right to limit the scope and length of the supplementary material Supplementary material must meet production quality standards for Web publication without the need for any modification or editing. In general, supplementary files should not exceed $10 \mathrm{MB}$ in size. All figures and tables should have title and legends and all files should be supplied separately and named clearly. Acceptable files and formats are: Word or PDF files, Excel spreadsheets (only if the data cannot be converted properly to a PDF file), and video files (.mov, .avi, .mpeg).

\section{KARGER}

Fax +4161306 1234 E-Mail karger@karger.ch www.karger.com
(C) 2012 S. Karger AG, Basel 


\section{Neurio}

endocrinology
ISSN Print Edition: 0028-3835

ISSN Online Edition: 1423-0194

Journal Homepage: www.karger.com/nen

Publication Data: 'Neuroendocrinology' is published 8 times a year. Volumes 95 and 96, each with 4 issues, appear in 2012

Copyright: (c) 2012 S. Karger AG, Basel (Switzerland). translated into other languages, reproduced or utilized in any form or by any means, electronic or mechanical, by any information storage and retrieval system, without permission in writing from the publisher or, in the case of photocopying, direct payment of a specified fee to the Copyright Clearance Center.

Disclaimer: The statements, opinions and data contained in this publication are solely those of the individual authors and contributors and not of the publisher and the editor(s). The appearance of advertisements in the journal is not a warranty, endorsement, or apeffectiveness, quality or safety. The publisher and the editor(s) disclaim responsibility for any injury to persons or property resulting from any ideas, methods, instructions or products referred to in the content or advertisements. All rights reserved. No part of this publication may be including photocopying, recording, microcopying, or proval of the products or services advertised or of their
Subscription Rates: Subscriptions run for a full calendar year. Prices are given per year. Personal subscription:

Print or Online

CHF 1618.-

EUR 1294-

USD 1572.00 CHF 1714.-

EUR 1370.-

USD 1666.00

postage and handling (added to print and print+online)

CHF 54.40 Europe, CHF 80.- Overseas

EUR 41.60

USD 75.20

Institutional subscription

Print or Online

Print+Online combined

CHF 3236.-

EUR 2588.-

CHF 3560.-

postage and handling (added to print and print+online)

CHF 68.- Europe, CHF 100.- Overseas

EUR 52.-

USD 94.00

Airmail surcharge: CHF 68.- / USD 64.00

Discount subscription prices:

Int. Neuroendocrine Federation

Europ. Neuroendocrine Association
Print+Online combined
Back Volumes and Single Issues: Information on availability and prices of single print issues and print or electronic back volumes can be obtained from Customer Service at service@karger.ch.

Bibliographic Indices: This journal is regularly listed in bibliographic services, including Current Contents ${ }^{\circledR}$ and PubMed/MEDLINE.

Photocopying: This journal has been registered with the Copyright Clearance Center (CCC), as indicated by the code appearing on the first page of each article. For readers in the US, this code signals consent for copying of articles for personal or internal use, or for the personal or internal use of specific clients, provided that the stated fee is paid per copy directly to

Copyright Clearance Center Inc.

222 Rosewood Drive

Danvers, MA 01923 (USA)

A copy of the first page of the article must accompany payment. Consent does not extend to copying for general distribution, for promotion, for creating new works, or for resale. In these cases, specific written permission must be obtained from the copyright owner,

S. Karger AG, P.O. Box

CH-4009 Basel (Switzerland).
Subscription Orders:

Orders can be placed at agencies, bookstores, directly with the Publisher

\section{S. Karger AG}

Medical and Scientific Publishers

P.O. Box

CH-4009 Basel

Switzerland

(for courier services only:

Allschwilerstrasse 10

CH-4055 Basel)

t: +41613061111

f: +41613061234

w: www.karger.com e: karger@karger.ch or further Karger offices

or representatives:

Germany

Postfach

79095 Freiburg

Deutschland

(Hausadresse: Wilhelmstrasse 20A

79098 Freiburg)

$\mathrm{t}: \quad+49761452070$

f: +497614520714

e: information@karger.de

w: www.karger.de

Japan

Karger Japan, Inc.

Shiba Daimon Asahi Bldg. 2F

1-2-23 Shiba Daimon

Minato-ku

Tokyo 105-0012

Japan

$\mathrm{t}:+81364356242$

f: +81364356244

e: publisher@karger.jp

w: www.karger.jp
S. Karger GmbH

Change of Address:

Both old and new address should be sent

to the subscription source.
USA

S. Karger Publishers, Inc.

26 West Avon Road

P.O. Box 529

Unionville, CT 06085

USA

Toll free: +1 8008285479

t: +18606757834

f: +18606757302

e: karger@snet.net

France

Librairie Médi-Sciences Sar

36, bd de Latour-Maubourg

75007 Paris

France

$\mathrm{t}:+33(0) 145514258$

f: $+33(0) 145560780$

e: librairie@medi-sciences.f

w: librairie@medi-sciences.

Gulf Council Countries, Iran,

Middle East, North Africa, Turkey

Trans Middle East International

Distribution Co. Ltd.

KaSha

134 Queen Rania Al Abdullah Street

Jordan Trade Center Bldg. 3rd Floor

P.O. Box 2376

Jordan

$\mathrm{t}:+96265153467$

f: +96265153472

e: info@kasha.cc

w: www.KaShaonline.com
Amman 11953
South East Asia, China and Taiwan Karger Regional Office (Malaysia)

CEO Suite Kuala Lumpur

Quill 7, 27th Floor

Jalan Stesen Sentral 5

KL Sentral

Kuala Lumpur 50470

Malaysia

t: +60327766803

f: +60327766999

e: service@karger.cn; r.chew@karger.cn

Karger China

10th Floor, Twin Towers (East)

B12 Jianguomenwai Avenue

Beijing 100022

China

$\mathrm{t}:+861051235033$

f: +861051235122

e: service@karger.cn; r.chew@karger.cn

w: www.karger.cn

India, Bangladesh, Sri Lanka

Medscience India

Plot No. 17, Yusuf Sarai Market

B.L. Glass Building, 2nd Floor

Sri Aurobindo Marg

New Delhi 110016

India

t: +911146029633

f: +911146029634

c: +919891052128

e: medsci.india@gmail.com

\section{KARGER}

Fax +41 613061234

E-Mail karger@karger.ch

www.karger.com
(C) 2012 S. Karger AG, Basel

The Journal Home Page is available at:

www.karger.com/nen 


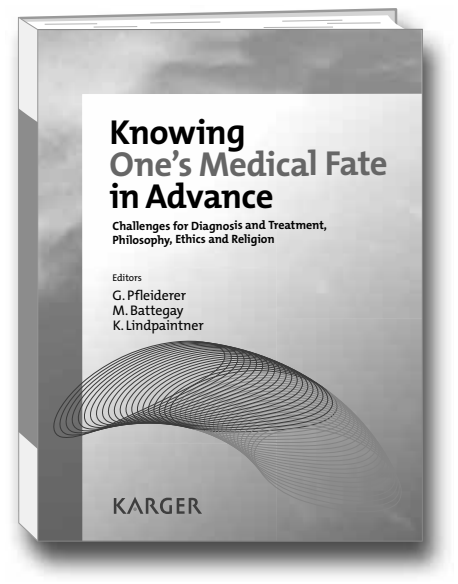

Modern medicine is now in a position to make advanced prognoses that chart the entire course of illness and recovery. Paradoxically, this is coupled with a new dimension of uncertainty for the patient, i.e. coming to terms with discovering they have an increased risk of a particular disease and deciding what appropriate steps to take. In this publication, renowned experts in their fields discuss these issues.

The certainty and uncertainty of one's fate are discussed from both methodological and epidemiological perspectives, using examples of diseases for which treatment and prognosis have dramatically changed. Despite profound insights into the human genome, personalized genetically tailored medicine still lies in the future. Religious, spiritual and philosophical dimensions are discussed, as are the ways in which they may help people cope with these new insights into their future, e.g. the promise of an afterlife.

This publication aims to bridge the different fields dealing with this area by addressing the challenges faced and encouraging dialogue. It will be of interest to all readers who deal with ethical problems of prognosis, particularly in medicine, as well as to theologians and sociologists.

\title{
Knowing One's Medical Fate in Advance
}

\section{Challenges for Diagnosis and Treatment, Philosophy, Ethics and Religion}

\author{
Editors \\ Georg Pfleiderer \\ Manuel Battegay \\ Klaus Lindpaintner
}

\section{Contents}

Introduction: Pfleiderer, G.; Battegay, M.; Lindpaintner, $K$.

\section{Medical Perspectives}

- Evolving Therapy and Prognosis in HIV - How Knowing One's Medical Fate in Advance Can Change Dramatically: Battegay, $M$.

- Related to Human Cognition: Is Personalization Feasible and Desirable?: Papassotiropoulos, $A$.

\section{Ethical and Juridical Perspectives}

- Ethical Decision-Making on Genetic Diagnosis Facing the Challenges of Knowing One's Medical Fate in Advance: Brahier, G.

- Mastering Familial Genetic Knowledge: Shared or Secret? Issues of DecisionMaking in Predictive Genetic Testing: Brüninghaus, A.; Porz, $R$.

- Predictive Medicine - Changes in Our View of Ourselves and Others: Birnbacher, $\boldsymbol{D}$.

- Current Challenges for the Law: Disclosure Dilemmas in Predictive Medicine: Dörr, B.S.

\section{Religious Perspectives}

- Fate and Judaism - Philosophical and Clinical Aspects: Gesundheit, B.

- Modern Medicine and My Future Life: A Christian-Theological Perspective: Pfleiderer, $\mathbf{G}$.

- Karma, Contingency, and the 'Point of No Return': Predictive Medicine and Buddhist Perspectives: Schlieter, J.

\section{Author Index}

Subject Index

\section{KARGER}

www.karger.com/medical-fate

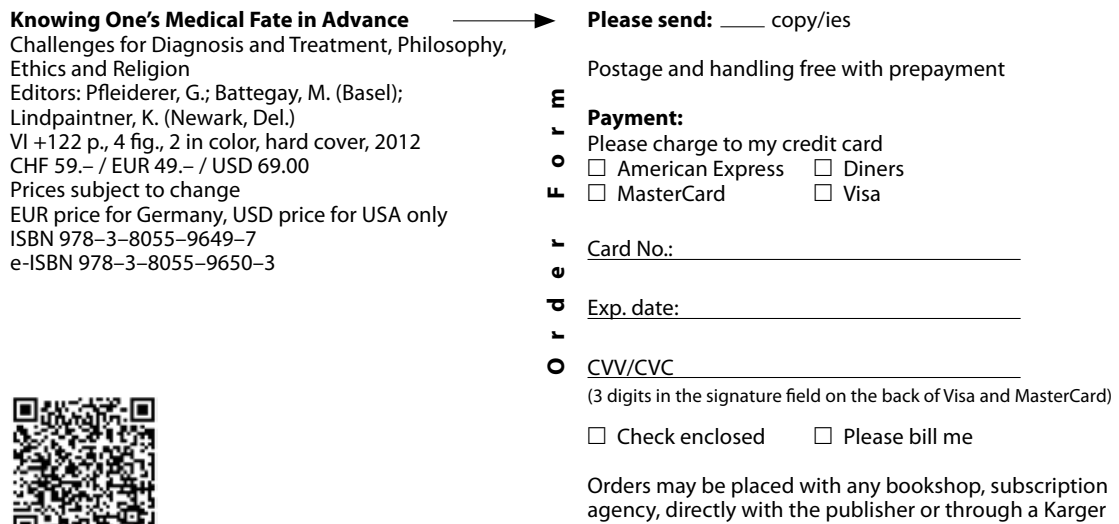

E

Postage and handling free with prepayment

Payment:

- Please charge to my credit card

- $\square$ American Express $\square$ Diners

ᄂ $\square$ MasterCard $\square$ Visa

Card No.

Exp date:

C CVV/CVC

( 3 digits in the signature field on the back of Visa and MasterCard)

$\square$ Check enclosed $\quad \square$ Please bill me

Orders may be placed with any bookshop, subscription agency, directly with the publisher or through a Karger distributor.
Fax: +41613061234

S. Karger AG, P.O. Box, CH-4009 Basel (Switzerland) E-Mail orders@karger.ch,www.karger.com

Name/Address: 


\section{Contents}

See the journal website for contents

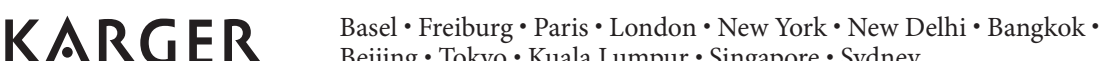
Beijing $\cdot$ Tokyo $\cdot$ Kuala Lumpur $\cdot$ Singapore $\cdot$ Sydney 
Under the auspice of:

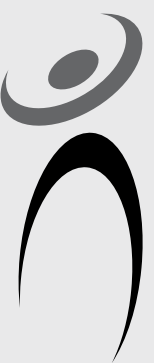

Endocrine Section of the Serbian Medical Society Endocrine Society of the Slovenian Medical Association

Serbian Society for Reproductive Endocrinology

\section{INTERNATIONAL SYMPOSIUM ON ADVANCES IN PCOS}

16-17 NOVEMBER 2012

BELGRADE, SERBIA

FIRST ANNOUNCEMENT AND CALL FOR ABSTRACT

ABSTRACT DEADLINE: 15 SEPTEMBER 2012

Organizers:

Djuro Macut, Serbia

Marija Pfeifer, Slovenia

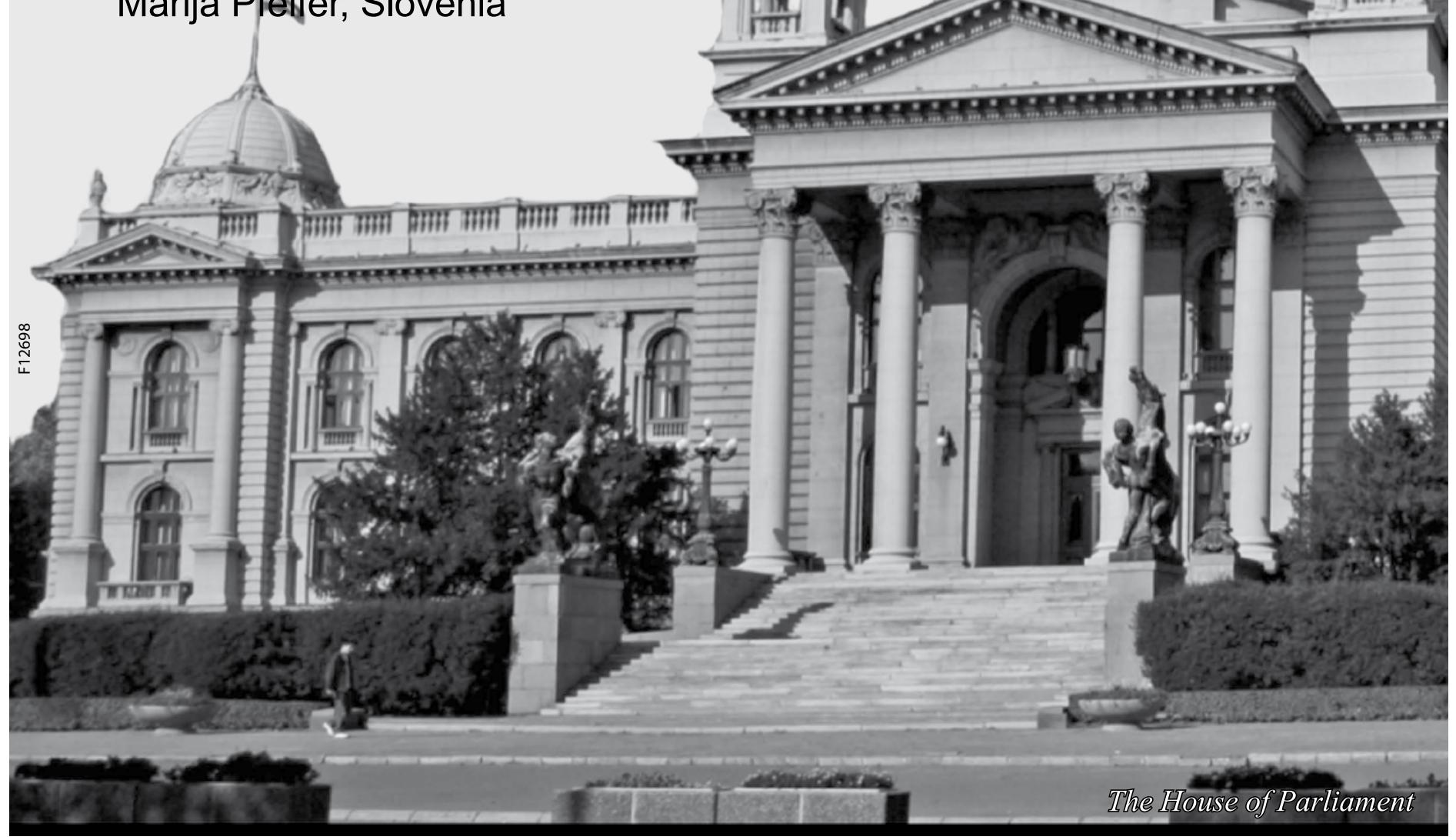




\section{Intensivkurs Schilddrüsenerkrankungen}

Düsseldorf 02. bis 04. November 2012

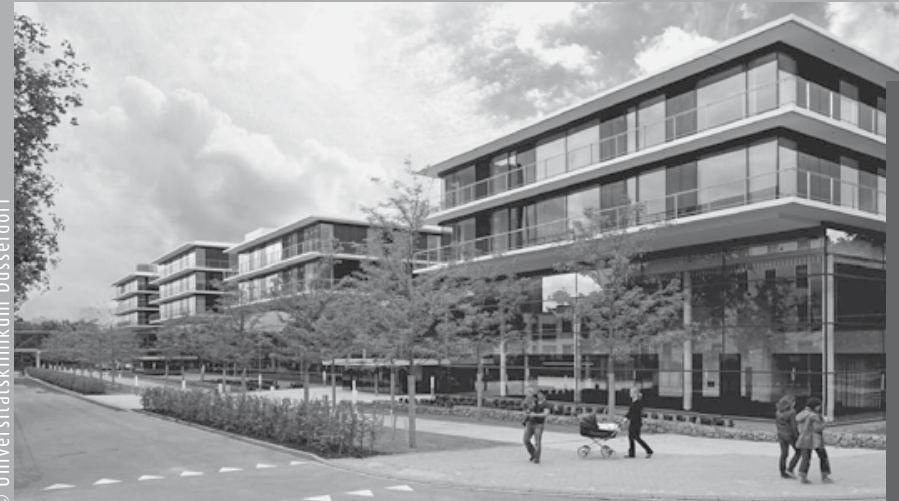

Universitätsklinikum Düsseldorf Hörsaalgebäude der MNR-Klinik

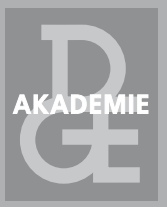

WISSENSCHAFTLICHE LEITUNG

Prof. Dr. Matthias Schott, Düsseldorf

Priv. Doz. Dr. Joachim Feldkamp, Bielefeld

TAGUNGSGEBÜHR

Niedergelassene/Fachärzte

Hauptkurs

Sonographiekurs

$350,-€$

Assistenzärzte

Hauptkurs

Sonographiekurs:

Studenten * (nur Hauptkurs)

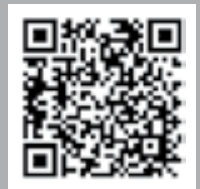

Weitere Information und Anmeldung

bei http://www.endokrinologie.net/veranstaltungen.php\#02.11.12-04.11.12

Organisation: Endoscience Endokrinologie Service GmbH, Hopfengartenweg 19, 90518 Altdorf E-Mail: info@endoscience.de

F12687

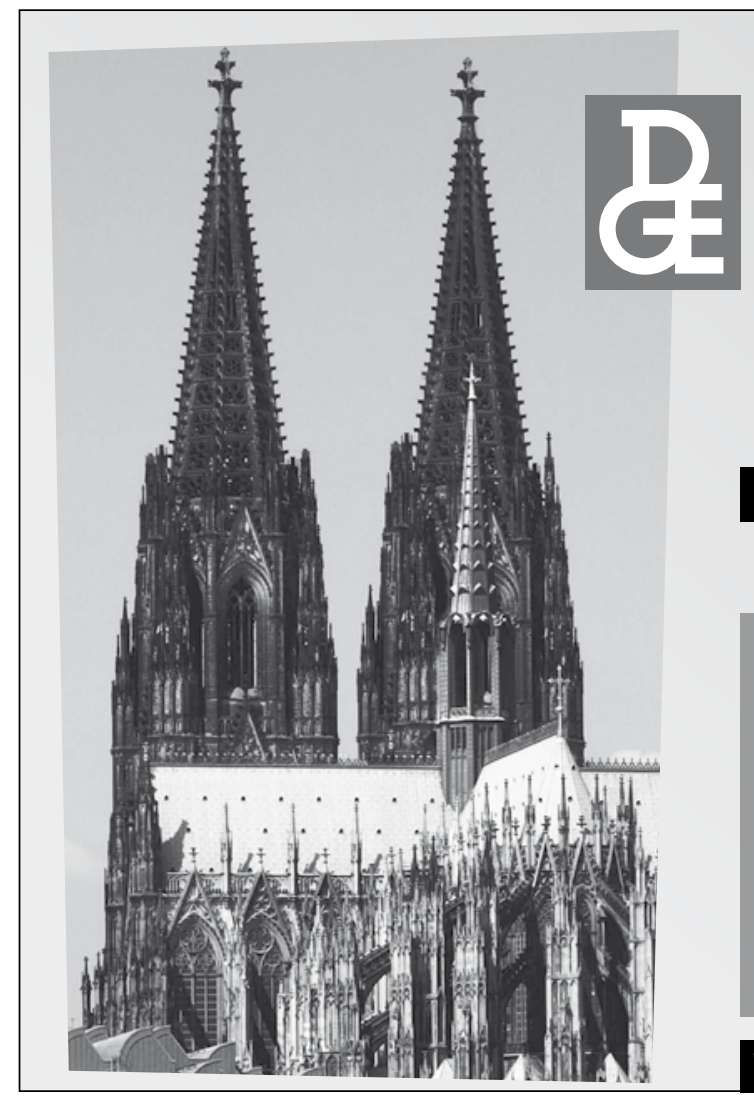

16. Jahrestagung der Sektion Neuroendokrinologie der DGE

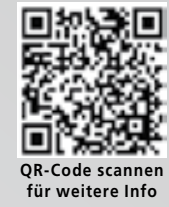
back-to-back mit der Herbstsitzung AG Hypophyse und Hypophysentumore

\section{9. - 30. November 2012}

Universitätsklinikum Köln

\section{TOPICS DER SEKTIONSTAGUNG}

Kraniopharyngeome

Zentrale Regulation

von Energie- und

Kohlenhydratstoffwechsel

Geschlechtsentwicklungs-

und -identitätsstörung

Gemeinsames Symposium

AG Hypophyse / SNE

Hot Topics

\section{KONTAKTADRESSEN}

EndoScience

Endokrinologie Service $\mathbf{G m b H}$ Hopfengartenweg 19, 90518 Altdorf

T. +49-(0)9187-97424-11

F. +49-(0)9187-97424-71

E-Mail.info@endoscience.de

Frau Dr. Johanna Pickel

MPI für Psychiatrie München

T. +49-(0)89-30622-460

E-Mail.pickel@mpipsykl.mpg.de 


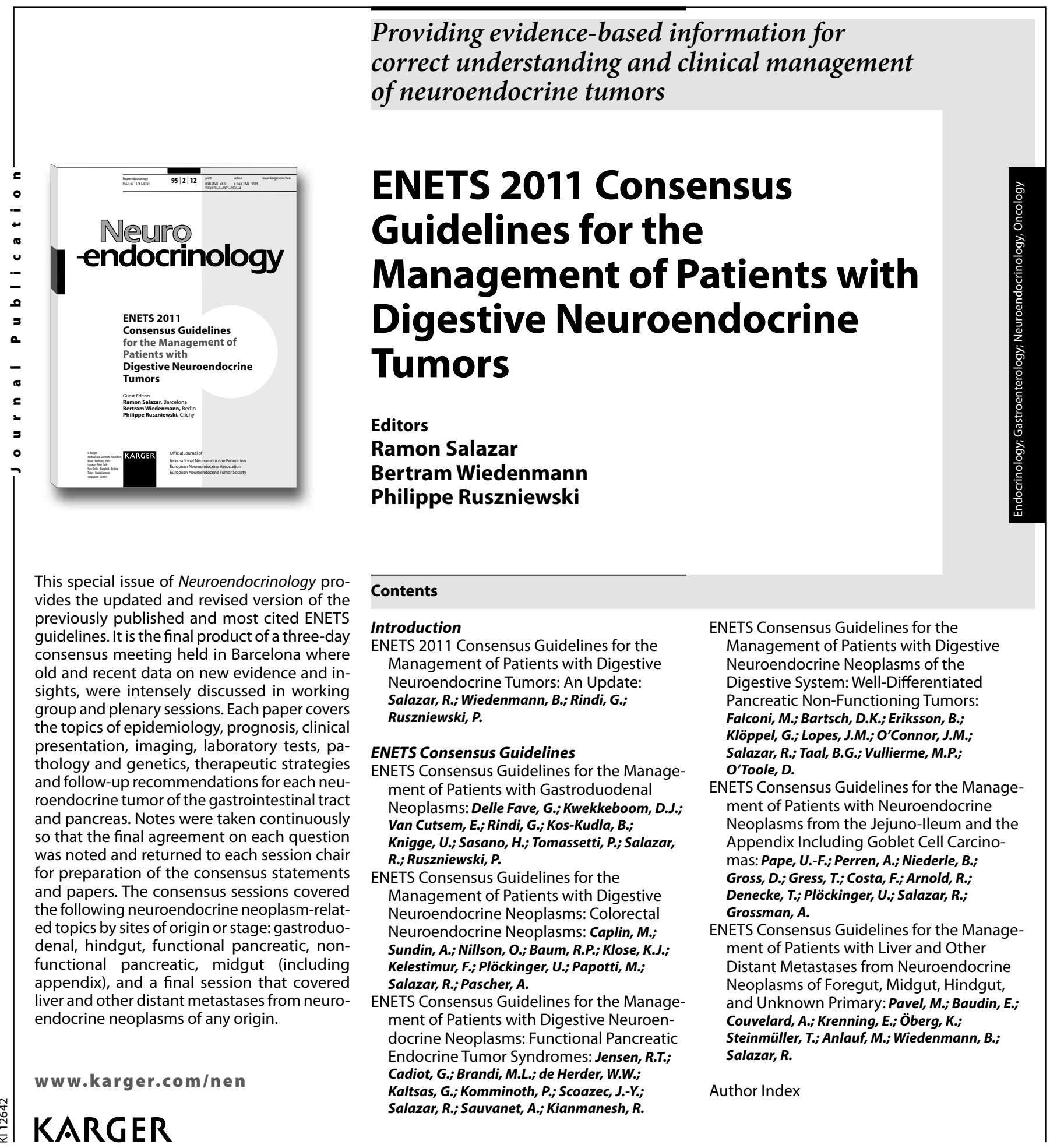

\section{ENETS 2011 Consensus Guidelines for} the Management of Patients

with Digestive Neuroendocrine Tumor

Editors: Salazar, R. (Barcelona); Wiedenmann, B.

(Berlin); Ruszniewski, P. (Clichy)

112 p., 7 fig., 2 in color, 9 tab., hard cover, 2012

CHF 39.- / EUR 33.- / USD 46.00

Prices subject to change

EUR price for Germany, USD price for USA only

ISBN 978-3-8055-9976-4 / e-ISBN 978-3-8055-9977-1 .

Special Topic Issue:

Neuroendocrinology

Vol. 95, No. 2 (2012)

Included in subscription

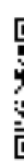

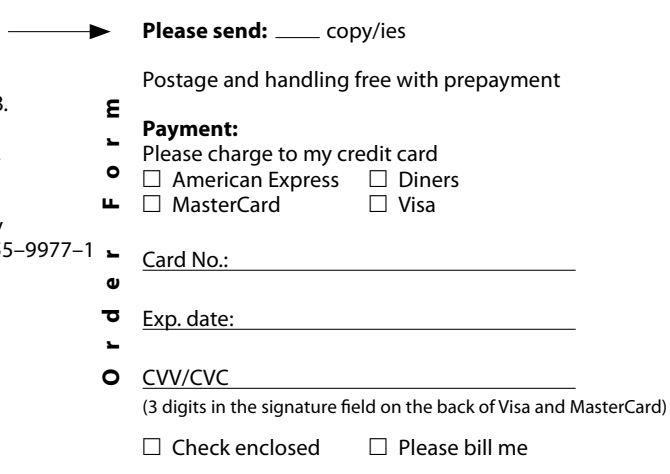

Orders may be placed with any bookshop, subscription agency, directly with the publisher or through a Karger distributor.
Fax: +41 613061234

S. Karger AG, P.O. Box, CH-4009 Basel (Switzerland) E-Mail orders@karger.ch, www.karger.com

Name/Address: 


\section{New journal}

European

Thyroid Journal

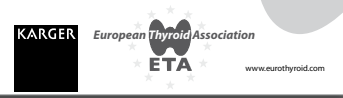

Editor-in-Chief

Wilmar M. Wiersinga,

Amsterdam

Associate Editors

Josef Koehrle, Berlin

(Basic Thyroidology)

Peter Laurberg, Aalborg

(Clinical Thyroidology)

Furio Pacini, Siena

(Thyroid Cancer)

Luca Persani, Milan

(Translational Thyroidology)

\section{Editorial Board}

Maria Alevizaki, Athens

Ana Aranda, Madrid

Rebecca Bahn, Rochester, Minn.

Paul Banga, London

Luigi Bartalena, Varese

Bernadette Biondi, Naples

Anita Boelen, Amsterdam

Georg Brabant, Lubeck

Henning Dralle, Halle

Murat Erdogan, Ankara

Valentin Fadeyev, Moscow

Ulla Feldt-Rasmussen,

Copenhagen

Laszlo Hegedus, Odense

George J. Kahaly, Mainz

Rui Maciel, São Paolo

Ana Luiza Maia, Porto Alegre

Jens Mittag, Stockholm

Ralf Paschke, Leipzig

Simon Pearce,

Newcastle-upon-Tyne

Robin P. Peeters, Rotterdam

Kris Poppe, Brussells

Samuel Refetoff, Chicago, III.

Jacques Samarut, Lyon

Pilar Santisteban, Madrid

Johannes Smit, Leiden

Mark Vanderpump, London

Theo Visser, Rotterdam

Paolo Vitti, Pisa

Graham R. Williams, London

Shunichi Yamashita, Nagasaki

Mariastella Zannini, Naples
Call for papers

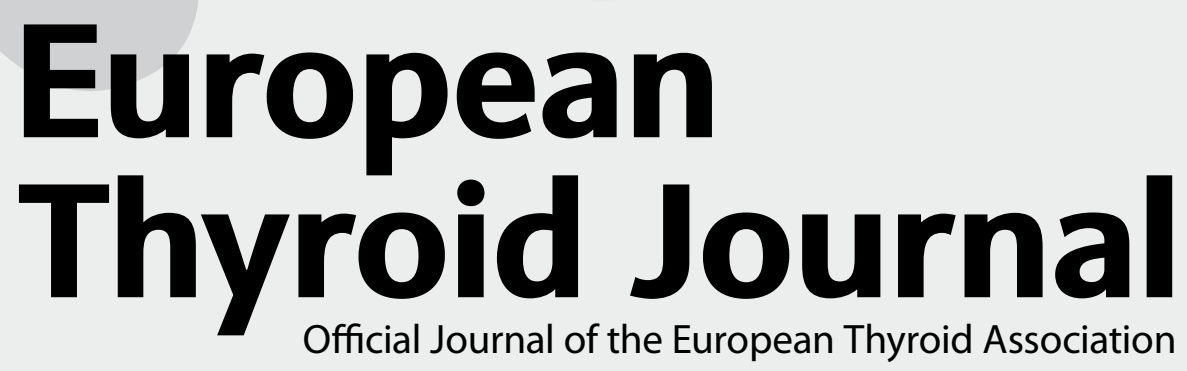

The European Thyroid Journal publishes papers reporting original research in basic, translational and clinical thyroidology. Original contributions cover all aspects of the field, from molecular and cellular biology to immunology and biochemistry, from physiology to pathology, and from pediatric to adult thyroid diseases with a special focus on thyroid cancer. Readers also benefit from reviews by noted experts, which highlight especially active areas of current research. The journal will further publish formal guidelines in the field, produced and endorsed by the European Thyroid Association.

\section{Call for papers}

The editors cordially invite you to submit your research papers to the European Thyroid Journal. Manuscripts written in English can be submitted online. Detailed Online Submission Instructions with a link to the Submission Website are at $\mathbf{w} \mathbf{w} \mathbf{w}$. karger.com/etj. Before submitting your manuscript, you are encouraged to review the detailed guidelines at $\mathbf{w} \mathbf{w} \mathbf{w}$. karger.com/eti_guidelines for specific directions as how to get a manuscript ready for submission.

\section{European Thyroid Journal}

2012: Vol. 1 with 4 issues

Language: English

ISSN 2235-0640

e-ISSN 2235-0802

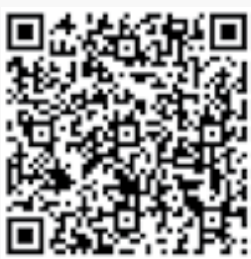

Official Journal of the

KARGER
European Thyroid Association 
endocrinology

At the Cutting Edge

1 Neuroendocrine Control of the Transition to Reproductive Senescence: Lessons Learned from the Female Rodent Model

Kermath, B.A.; Gore, A.C. (Austin, Tex.)

13 Antioxidant Therapies: A Potential Role in Perinatal Medicine

Miller, S.L.; Wallace, E.M.; Walker, D.W. (Clayton, Vic.)

Original Papers

24 Intracerebroventricular Administration of Metformin Inhibits Ghrelin-Induced Hypothalamic AMP-Kinase Signalling and Food Intake

Stevanovic, D.; Janjetovic, K.; Misirkic, M.; Vucicevic, L.; Sumarac-Dumanovic, M.; Micic, D.; Starcevic, V.; Trajkovic, V. (Belgrade)

32 Risk Factors for Disease Progression in Advanced Jejunoileal Neuroendocrine Tumors

Panzuto, F. (Rome); Campana, D. (Bologna); Fazio, N. (Milan); Brizzi, M.P. (Turin);

Boninsegna, L. (Verona/Negrar); Nori, F. (Bologna); Di Meglio, G. (Milan); Capurso, G. (Rome); Scarpa, A. (Verona); Dogliotti, L. (Turin); De Braud, F. (Milan); Tomassetti, P. (Bologna);

Delle Fave, G. (Rome); Falconi, M. (Verona)

41 Neuroprotective Role of Estradiol against Neuronal Death Induced by Glucose Deprivation in Cultured Rat Hippocampal Neurons

Hernández-Fonseca, K.; Massieu, L.; García de la Cadena, S.; Guzmán, C.; Camacho-Arroyo, I. (México)

51 Involvement of $\alpha_{2}$-Adrenoceptor Subtypes A and C in Glucose Homeostasis and Adrenaline-Induced Hyperglycaemia

Ruohonen, S.T.; Ruohonen, S. (Turku/Freiburg); Gilsbach, R. (Freiburg); Savontaus, E.; Scheinin, M. (Turku); Hein, L. (Freiburg)

60 Progesterone Receptor Isoform Expression in Response to in utero Growth Restriction in the Fetal Guinea Pig Brain

Palliser, H.K.; Yates, D.M.; Hirst, J.J. (Newcastle, N.S.W.)

68 Kisspeptin Inhibits High-Voltage Activated $\mathrm{Ca}^{2+}$ Channels in GnRH Neurons via Multiple $\mathrm{Ca}^{2+}$ Influx and Release Pathways

Zhang, X.-B. (Chicago, Ill.); Spergel, D.J. (Chicago, Ill./New Haven, Conn.)

81 Inhibitory Effects of GHRH Antagonists on Human GH-Secreting Adenoma Tissue Szalontay, L.; Benveniste, R.J.; Schally, A.V.; Vidaurre, I.; Nadji, M. (Miami, Fla.); Zarandi, M. (Miami, Fla./Szeged); Block, N.L. (Miami, Fla.); Kovacs, M. (Miami, Fla./Pécs)

89 ENETS Newsletter Summer/Fall 2012

\section{KARGER}

